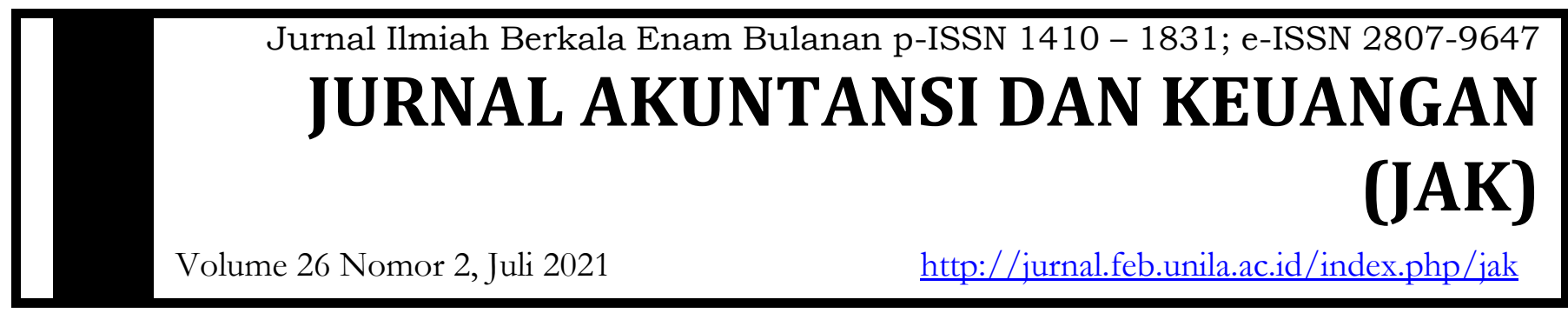

\title{
ANALISIS PENDAPATAN BERBASIS KAS DAN BERBASIS AKRUAL DALAM LAPORAN KEUANGAN PEMERINTAH DAERAH
}

\author{
Monica Valencia Putri' ${ }^{1}$, Rindu Rika Gamayuni' ${ }^{2}$, Komaruddin $^{3}$, Fitra Dharma ${ }^{4}$ \\ ${ }^{1}$ Fakultas Ekonomi dan Bisnis, Universitas Lampung \\ ${ }^{2}$ Fakultas Ekonomi dan Bisnis, Universitas Lampung \\ 3 Fakultas Ekonomi dan Bisnis, Universitas Lampung \\ 4 Fakultas Ekonomi dan Bisnis, Universitas Lampung
}

\section{Informasi Naskah}

Update Naskah:

Dikumpulkan: 16 Mei 2021

Diterima: 20 Juni 2021

Terbit/Dicetak: 31 Juli 2021

\section{Keywords:}

cash basis income, accrual basis income, accrual-based SAP, LRA-

Income and LO-income.

\section{Abstract}

This study aims to examine cash basis income (LRA-income) and accrual basis income (LO-income) in the financial statement of provincial governments in Indonesia. The sample in this study used 33 provinces in Indonesia within a period of 10 years from 2010-2019. The results of this study indicate that there is a significant difference in the increase in the total income of LRA-LRA and LRA-LO in provincial LKPD in Indonesia before and after the application of accrual based $S A P$. There is a significant difference in the increase in local revenue of $L R A-L R A$ and $L R A-L O$ in provincial $L K P D$ in Indonesia before and after the application of accrual-based $S A P$. There is a significant difference in the increase in local taxes LRA-LRA and LRA-LO in provincial LKPD in Indonesia before and after the application of accrual-based SAP. There is a significant difference in the decrease in regional levies LRA-LRA and LRA-LO in provincial LKPD in Indonesia before and after the application of accrual-based SAP. 
Di Indonesia sektor publik berkembang mengikuti laju dan aturan dari pemerintah yang sudah diterapkan. Dalam mewujudkan suatu sistem tata kelola pemerintahan yang baik, salah satunya yaitu dengan adanya perubahan di bidang akuntansi pemerintahan. Perubahan tersebut harus didasari dengan adanya Standar Akuntansi Pemerintah (SAP). SAP merupakan peraturan pemerintah yang diterapkan untuk entitas pemerintah dalam penyusunan laporan keuangan pemerintah pusat dan daerah. SAP ini dibuat untuk menjamin adanya transparansi, partisipasi, dan akuntabilitas dalam pengelolaan keuangan negara untuk mewujudkan pemerintahan yang baik dan bersih.

Perubahan pada sektor publik, yaitu terjadi pada perubahan sistem akuntansi dari akuntansi berbasis kas menjadi akuntansi berbasis akrual. Hal ini dikarenakan pada sistem akuntansi berbasis kas dianggap kurang memuaskan dalam pelaporan keuangannya, terutama masih terdapat kekurangan dalam menyajikan gambaran keuangan yang akurat, minim informasi manajemen yang berguna dan belum cukup memadai untuk memfasilitasi perencanaan dan proses kinerja pada pemerintahan daerah.

Dasar akuntansi yang dianggap memenuhi tuntutan tentang laporan keuangan adalah sistem akuntansi yang berbasis akrual. Akan tetapi, karena penerapan basis akrual secara sepenuhnya pada sistem akuntansi keuangan daerah memerlukan banyak perubahan pada sumber daya manusia dan teknologi, maka penerapan basis akrual dilakukan secara bertahap melalui suatu proses transisi, yaitu mulai dari akuntansi berbasis kas, akuntansi berbasis kas menuju akrual, dan akuntansi berbasis akrual. Tujuan memperkenalkan sistem akuntansi akrual adalah untuk membantu meningkatkan transparansi, memperbaiki efisiensi dan efektivitas pada sektor publik (Hyndman dan Connolly, 2010).

Menurut Khan (2016) dengan bantuan sistem akrual, informasi terkait pendapatan dan pengeluaran dapat dirinci sesuai dengan yang diharapkan. Seiring dengan kemajuan waktu, akuntansi berbasis akrual dianggap sebagai alat dasar pelaporan keuangan yang akan menghasilkan peningkatan informasi untuk pengambilan keputusan dan penilaian kinerja keuangan. Pada Tahun 2010, pemerintah mengeluarkan peraturan baru tentang Standar Akuntansi Pemerintah (SAP) melalui Peraturan Pemerintah Nomor 71 Tahun 2010, yang mengatur tentang penggunaan basis akrual dalam pengelolaan dan pelaporan keuangan pemerintah, untuk menggantikan Peraturan Pemerintah Nomor 24 Tahun 2005. Perubahan ini dilakukan karena pemerintah menganggap bahwa akuntansi berbasis kas kurang memuaskan dan belum efisien dalam penggunaannya. Penerapan SAP berbasis akrual ini ditetapkan oleh pemerintah bahwa secara penuh harus diterapkan mulai tahun anggaran 2015.

Menurut Wibowo et al., (2018) terdapat dua istilah pendapatan pada akuntansi pemda, yaitu pendapatan untuk laporan realisasi anggaran dan pendapatan untuk laporan operasional. Kedua istilah ini disebabkan pendapatan akan dilaporkan di dua laporan yaitu pada Laporan Operasional (LO) dan Laporan Realisasi Anggaran (LRA). Pada dua laporan ini nantinya akan digunakan juga pada saat penjurnalan.

Dalam penerapan sistem akuntansi pada pendapatan-LRA dan pendapatan-LO menggunakan basis akuntansi yang berbeda sehingga pengakuannya juga berbeda. Dalam PP Nomor 71 Tahun 2010 pendapatan-LRA tetap menggunakan basis kas, sedangkan untuk pendapatan-LO menggunakan basis akrual. Perbedaan dalam pengakuan pendapatan-LRA dan pendapatan-LO ini menyebabkan jumlah akunakun kedua pendapatan tersebut berbeda.

\section{B. LANDASAN TEORI DAN PENGEMBANGAN HIPOTESIS}

\section{Teori New Public Management (NPM)}

New Public Management merupakan teori manajemen publik yang beranggapan bahwa praktik manajemen sektor swasta lebih baik dari praktik manajemen sektor publik. Oleh karena itu, untuk memperbaiki kinerja sektor publik perlu diadopsi beberapa praktik dan teknik manajemen yang diterapkan di sektor swasta (Sayidah et al., 2015). Menurut Syarienda et al., (2019) dengan adanya perubahan pada 
sektor publik, terjadi pula perubahan pada akuntansi sektor publik. Akuntansi sektor publik kemudian mengikuti dan menyesuaikan diri dengan perubahan-perubahan yang terjadi, sebagai contoh yaitu terjadinya perubahan sistem akuntansi dari akuntansi berbasis kas menjadi akuntansi berbasis akrual.

\section{Basis Akuntansi}

\section{Akuntansi Cash Basis}

Dalam PP No. 71 Tahun 2010 menyatakan bahwa akuntansi berbasis kas digunakan untuk Laporan Realisasi Anggaran (LRA), yang berarti bahwa pendapatan diakui pada saat kas diterima di Rekening Kas Umum Negara/Daerah atau oleh entitas pelaporan dan belanja diakui pada saat kas dikeluarkan dari Rekening Kas Umum Negara/Daerah atau entitas pelaporan. Entitas pelaporan tidak menggunakan istilah laba. Penentuan sisa pembiayaan anggaran lebih baik ataupun kurang untuk setiap periode tergantung pada selisih realisasi penerimaan dan pengeluaran. Pendapatan dan belanja bukan tunai seperti bantuan pihak luar asing dalam bentuk barang dan jasa disajikan pada Laporan Ralisasi Anggaran.

\section{Akuntansi Accrual Basis}

Dalam PP No. 71 Tahun 2010 menyatakan bahwa basis akrual digunakan untuk neraca, yang berarti bahwa asset, kewajiban, dan ekuitas dana diakui dan dicatat pada saat terjadinya transaksi, atau pada saat kejadian atau kondisi lingkungan berpengaruh pada keuangan pemerintah, tanpa memperhatikan saat kas atau setara kas diterima atau dibayar. Dalam Laporan Operasional basis yang digunakan adalah basis akrual, yang berarti bahwa pendapatan-LO diakui pada saat timbulnya hak atas pendapatan, dan pendapatan direalisasi, yaitu adanya aliran sumber daya ekonomi ke entitas.

\section{Perbedaan Pendapatan-LRA dan Pendapatan-LO Sebelum dan Sesudah Penerapan Sistem Akuntansi Pemerintah Berbasis Akrual}

Dengan berubahnya Peraturan Pemerintah No. 24 Tahun 2005 tentang SAP berbasis kas menjadi Peraturan Pemerintah No. 71 Tahun 2010 tentang SAP berbasis akrual, maka akan berubah pula pencatatan dan penyajian dalam penyusunan laporan keuangan pemerintah. Dalam penelitian yang dilakukan oleh Hijriah (2020), penyajian laporan keuangan BPKAD Kota Palopo dilaksanakan berdasarkan basis kas, berarti bahwa pendapatan-LRA dan penerimaan pembiayaan diakui pada saat kas diterima di KUD atau entitas pelaporan, serta belanja, dan pengeluaran pembiayaan diakui pada saat kas dikeluarkan dari rekening KUD. Untuk laporan operasional pada laporan keuangan, Kota Palopo menggunakan basis akrual dalam penyajiannya.

Penelitian yang dilakukan oleh Wibowo et al., (2018) menyatakan bahwa terdapat perbedaan yang signifikan dalam laporan keuangan pemerintah daerah Jawa Tengah antara pendapatan-LRA sebelum dan sesudah penerapan SAP berbasis akrual. Sedangkan untuk pendapatan-LO dan pendapatan-LRA setelah penerapan SAP berbasis akrual menyatakan tidak terdapat perbedaan yang signifikan. Untuk pendapatanLRA terdapat perbedaan yang signifikan didukung oleh penelitian yang dilakukan oleh Subadriyah (2017) yang menyatakan bahwa PAD mengalami peningkatan dibandingkan sebelum penerapan SAP berbasis akrual.

Perbedaan yang mendasar pada sistem akuntansi pemerintah berbasis kas dan berbasis akrual yaitu dalam hal pendapatan. Pendapatan dalam akuntansi berbasis kas dikaui pada saat dana kas diterima/dibayarkan. Sedangkan untuk pendapatan dalam basis akrual pendapatan diakui pada saat terjadinya transaksi tanpa melihat kapan kas diterima/dibayarkan. Dalam penelitian Pramudiati (2019) menyatakan bahwa pengakuan pendapatan pada LKPD setelah penerapan SAP berbasis akrual lebih akurat sehingga perbandingan antara realisasi dan target semakin kecil dibandingkan sebelum penerapan SAP berbasis akrual. Penerapan sistem akuntansi berbasis akrual dapat meningkatkan kualitas serta akuntabilitas khususnya pada sektor publik. Penelitian yang dilakukan oleh Grace N (2014) mengungkapkan bahwa 
adopsi dan implementasi akuntansi akrual IPSAS di Nigeria akan secara signifikan meningkatkan akuntabilitas, transparansi, dan juga meningkatkan informasi keuangan dengan pengelanan dan penerapan IPSAS di Sektor Publik Nigeria. Fenomena yang terjadi pada sistem akuntansi pemerintahan ini merupakan suatu hal yang menarik untuk dikaji lebih lanjut, karena dengan berubahnya sistem akuntansi maka akan berubah pula sistem dalam penyusunan laporan keuangan baik dalam hal pengakuan, penilaian, penyajian dan kebijakan lainnya. Dalam hal ini juga, akan mempengaruhi kualitas laporan keuangan itu sendiri yang tergambar dari hasil pemeriksaan yang diberikan oleh BPK RI. Dalam penelitian Aidoo-Buameh (2014) cash basis menciptakan distorsi dalam sistem PSFM, dan rentan terhadap penyalahgunaan keuangan, penipuan dan penggelapan. Sedangkan penerapan accrual basis, alternatif superior yang diakui terus bertahan karena tidak adanya Political Will di pihaknya. Berdasarkan penjelasan yang telah dipaparkan, maka hipotesis yang diajukan adalah:

$H_{1}$ : Terdapat perbedaan total pendapatan-LRA dan total pendapatan-LO sebelum dan sesudah penerapan SAP berbasis akrual.

$H_{2}$ : Terdapat perbedaan PAD sebelum dan sesudah penerapan SAP berbasis akrual.

$\mathrm{H}_{2 \mathrm{a}}$ : Terdapat perbedaan pajak daerah sebelum dan sesudah penerapan SAP berbasis akrual.

$H_{2 b}$ : Terdapat perbedaan retribusi daerah sebelum dan sesudah penerapan SAP berbasis akrual.

\section{METODE PENELITIAN}

\section{Jenis dan Sumber Data}

Jenis data yang digunakan dalam penelitian ini adalah data kuantitatif, sedangkan sumber data yang digunakan adalah data sekunder. Data sekunder yang digunakan dalam penelitian ini terdiri dari data komponen Laporan Keuangan Pemerintah Daerah (LKPD) Provinsi di Indonesia tahun anggaran 20102019. Sumber data diperoleh dari Kantor Badan Pemeriksa Keuangan Republik Indonesia (BPK RI). Sumber data lainnya diperoleh dengan mengkaji dan memahami buku, jurnal-jurnal penelitian, serta skripsi terdahulu.

\section{Sampel}

Populasi dari penelitian ini adalah Pemerintah Daerah Provinsi di Indonesia. Dengan sampel yang digunakan dalam penelitian ini adalah Laporan Keuangan Pemerintah Daaerah (LKPD) Provinsi di Indonesia pada tahun 2010-2019.

\section{Definisi Operasional Variable}

\section{Pendapatan-LRA}

Pendapatan-LRA menurut PSAP No. 02 merupakan semua penerimaan rekening kas umum negara/daerah yang menambah saldo anggaran lebih dalam periode tahun anggaran yang bersangkutan yang menjadi hak pemerintah, dan tidak perlu dibayar kembali. Akuntansi pendapatan-LRA dilaksanakan berdasarkan azas bruto, yaitu dengan membukukan penerimaan bruto, dan tidak mencatat jumlah netonya. Dalam hal besaran pengurang terhadap pendapatan-LRA bruto (biaya) bersifat variabel terhadap pendapatan dimaksud dan tidak dapat dianggarkan terlebih dahulu dikarenakan proses belum selesai, maka azas bruto dapat dikecualikan. Dalam penelitian ini, pendapatan-LRA diukur dengan:

Pendapatan-LRA = Jumlah pendapatan dalam laporan realiasasi anggaran

\section{Pendapatan-LO}

Berdasarkan PSAP No. 12 pendapatan-LO adalah hak pemerintah pusat/daerah yang diakui sebagai penambah ekuitas dalam periode tahun anggaran yang bersangkutan dan tidak perlu dibayar kembali. 
Pendapatan-LO diakui pada saat timbulnya hak atas pendapatan dan pendapatan direalisasi, yaitu adanya aliran masuk sumber daya ekonomi. Dalam penelitian ini, pendapatan-LO diukur dengan:

Pendapatan-LO = Jumlah pendapatan dalam laporan operasional

\section{Pendapatan Asli Daerah (PAD)}

Menurut DJPK Kemenkeu, pendapatan asli daerah dipungut oleh pemerintah daerah berdasarkan peraturan daerah sesuai dengan peraturan perundang-undangan. PAD bertujuan memberikan kewenangan kepada pemerintah daerah untuk mendanai pelaksanaan otonomi daerah sesuai dengan potensi daerah sebagai perwujudan desentrasiliasi. Dalam penelitian ini, PAD diukur dengan:

$\mathrm{PAD}=$ Jumlah pendapatan asli daerah dalam laporan keuangan pemerintah daerah

\section{Pajak Daerah}

Menurut DJPK Kemenkeu, pajak daerah merupakan kontribusi wajib kepada daerah yang terutang oleh orang pribadi atau badan yang bersifat memaksa berdasarkan undang-undang, dengan tidak mendapatkan imbalan secara langsung dan digunakan untuk keperluan daerah bagi sebesar-besarnya kemakmuran rakyat. Dalam penelitian ini, pajak daerah diukur dengan:

Pajak daerah $=$ Jumlah pajak daerah dalam laporan keuangan pemerintah daerah

\section{Retribusi Daerah}

Menurut DJPK Kemenkeu, retribusi daerah merupakan pungutan daerah sebagai pembayaran atas jasa atau pemberian izin tertentu yang khusus disediakan dan/atau diberikan oleh pemerintah daerah untuk kepentingan orang pribadi atau badan. Dalam penelitian ini, retribusi daerah diukur dengan:

Retribusi daerah $=$ Jumlah retribusi daerah dalam laporan keuangan pemerintah daerah

\section{Metode Analisis Data}

\section{Statistik Deskriptif}

Analisis statistik deskriptif merupakan teknik deskriptif yang memberikan informasi mengenai data yang dimiliki dan tidak bermaksud menguji hipotesis. Statistik deskriptif berfungsi untuk medeskripsikan atau memberi gambaran terhadap obyek yang diteliti melalui data sampel/populasi sebagimana adanya tanpa melakukan analisis dan membuat kesimpulan yang berlaku secara umum.

\section{Uji Normalitas}

Uji normalitas dilakukan dengan tujuan untuk mendeteksi apakah sampel yang digunakan dalam penelitian ini terdistribusi secara normal atau tidak. Model regresi yang baik adalah yang memiliki distrubusi normal atau mendekati normal. Untuk mendeteksi normalitas data dapat dilakukan dengan uji metode one sample-kolmogorov-smirnov test. Sampel dinyatakan terdistribusi normal apabila asymptotic sig > tingkat keyakinan yang digunakan dalam pengujian. Sebaliknya dikatakan tidak normal apabila asymptotic sig < tingkat keyakinan, dalam hal ini adalah $95 \%$ atau $\alpha=5 \%$.

\section{Uji Hipotesis}

\section{Paired Sample t-test}

Paired sample t-test adalah uji-t yang digunakan untuk membandingkan mean dari satu sampel yang berpasangan (paired). Untuk paired sample t-test, kelompok sampel diberikan perlakuan yang sama dan setiap subyek memiliki dua buah skor yang berpasangan. Paired sample t-test bertujuan untuk mengkaji apakah suatu perubahan terjadi sebagai akibat dari perlakuan dengan membandingkan sebelum dan sesudah diberikan perlakuan. 


\section{Wilcoxon Signed-Rank Test}

Wilcoxon signed-rank test merupakan uji non-parametrik yang tidak mensyaratkan data berdistribusi normal. Uji ini sering digunakan sebagai alternatif pengganti dari paired sample t-test jika data tidak berdistribusi normal (Ghozali, 2013). Pengambilan keputusan didapat dari:

- Ho diterima apabila nilai probabilitas $\leq 0,05$.

- Ho ditolak apabila nilai probabilitas $>0,05$

\section{ANALISIS DAN PEMBAHASAN}

\section{Deksripsi Objek Penelitian}

\begin{tabular}{|l|l|c|}
\hline No. & \multicolumn{1}{|c|}{ Keterangan } & Jumlah \\
\hline 1. & Provinsi yang ada di Indonesia & 34 \\
\hline 2. & Provinsi Baru Tahun 2013 & $(1)$ \\
\hline Jumlah Sampel Provinsi & $\mathbf{3 3}$ \\
\hline Jumlah Sampel Provinsi $\times$ Periode Pengamatan $\mathbf{3 3} \times \mathbf{1 0})$ & $\mathbf{3 3 0}$ \\
\hline Jumlah Sampel & $\mathbf{3 3 0}$ \\
\hline
\end{tabular}

Provinsi di Indonesia pada saat ini berjumlah 34 provinsi, serta terdapat satu provinsi yang baru bergabung pada tahun 2013, yaitu Provinsi Kalimantan Utara, sehingga jumlah sampel provinsi yang digunakan dalam penelitian ini adalah 33 provinsi yang ada di Indonesia dan terdapat 330 LKPD selama rentang waktu 10 tahun.

\section{Statistik Deskriptif}

Berdasarkan hasil pengujian statistik deskriptif LRA-LRA diperoleh hasil sebagai berikut:

1. Pajak daerah sebelum penerapan akrual basis menunjukkan nilai mean sebesar Rp2.263.524 dengan standar deviasi sebesar Rp3.901.728 dan pajak daerah sesudah penerapan akrual basis menunjukkan nilai mean sebesar Rp3.786.759 dengan standar deviasi Rp6.780.003. Hasil menunjukkan nilai mean lebih kecil dari standar deviasi, artinya distribusi data pajak daerah tidak baik. Pajak daerah terendah sebesar Rp61.999 dimiliki oleh Provinsi Maluku Utara pada Tahun 2010, sedangkan pajak daerah tertinggi sebesar Rp40.298.100 dimiliki oleh Provinsi DKI Jakarta pada Tahun 2019.

2. Retribusi daerah sebelum penerapan akrual basis menunjukkan nilai mean sebesar Rp55.923 dengan standar deviasi Rp166.572 dan retribusi daerah sesudah penerapan akrual basis menunjukkan nilai mean sebesar Rp51.897 dengan standar deviasi Rp100.821. Hasil menunjukkan nilai mean lebih kecil dari standar deviasi, artinya distribusi data retribusi daerah tidak baik. Retribusi daerah terendah sebesar Rp66 dimiliki oleh Provinsi Gorontalo pada Tahun 2010, sedangkan retribusi daerah tertinggi sebesar Rp1.820.440 dimiliki oleh Provinsi DKI Jakarta pada Tahun 2012.

3. Total PAD sebelum akrual basis menunjukkan mean sebesar Rp2.668.341 dengan standar deviasi Rp4.555.168 dan total PAD sesudah akrual basis menunjukkan mean sebesar Rp4.438.406 dengan standar deviasi Rp7.843.797. Hasil menunjukkan nilai mean lebih kecil dari standar deviasi, artinya distribusi data total PAD tidak baik. Total PAD terendah sebesar Rp77.842 dimiliki oleh Provinsi Maluku Utara pada Tahun 2010, sedangkan total PAD tertinggi sebesar Rp45.707.400 dimiliki oleh Provinsi DKI Jakarta pada Tahun 2019.

4. Total pendapatan sebelum akrual basis menunjukkan mean sebesar Rp5.336.519 dengan standar deviasi Rp6.670.923 dan total pendapatan sesudah akrual basis menunjukan mean sebesar Rp9.227.285 dengan standar deviasi Rp11.175.983. hasil menunjukan nilai mean lebih kecil dari standar deviasi, artinya distribusi data total pendapatan tidak baik. Total pendapatan terendah sebesar Rp593.392 dimiliki oleh Provinsi Gorontalo pada Tahun 2010, sedangkan total pendapatan tertinggi 
sebesar Rp64.823.900 dimiliki oleh Provinsi DKI Jakarta pada Tahun 2017

Berdasarkan hasil pengujian statistik deskriptif LRA-LO diperoleh hasil sebagai berikut:

1. Pajak daerah sebelum penerapan akrual basis menunjukkan nilai mean sebesar Rp2.263.524 dengan standar deviasi sebesar Rp3.901.728 dan pajak daerah sesudah penerapan akrual basis menunjukkan nilai mean sebesar Rp3.824.942 dengan standar deviasi Rp6.856.149. Hasil menunjukkan nilai mean lebih kecil dari standar deviasi, artinya distribusi data pajak daerah tidak baik. Pajak daerah terendah sebesar Rp61.999 dimiliki oleh Provinsi Maluku Utara pada Tahun 2010, sedangkan pajak daerah tertinggi sebesar Rp40.700.800 dimiliki oleh Provinsi DKI Jakarta pada Tahun 2019.

2. Retribusi daerah sebelum penerapan akrual basis menunjukkan nilai mean sebesar Rp55.923 dengan standar deviasi Rp166.572 dan retribusi daerah sesudah penerapan akrual basis menunjukkan nilai mean sebesar Rp52.396 dengan standar deviasi Rp100.951. Hasil menunjukkan nilai mean lebih kecil dari standar deviasi, artinya distribusi data retribusi daerah tidak baik. Retribusi daerah terendah sebesar Rp66 dimiliki oleh Provinsi Gorontalo pada Tahun 2010, sedangkan retribusi daerah tertinggi sebesar Rp1.820.440 dimiliki oleh Provinsi DKI Jakarta pada Tahun 2012.

3. Total PAD sebelum akrual basis menunjukkan mean sebesar Rp2.668.341 dengan standar deviasi Rp4.555.168 dan total PAD sesudah akrual basis menunjukkan mean sebesar Rp4.995.176 dengan standar deviasi Rp10.049.549. Hasil menunjukkan nilai mean lebih kecil dari standar deviasi, artinya distribusi data total PAD tidak baik. Total PAD terendah sebesar Rp77.842 dimiliki oleh Provinsi Maluku Utara pada Tahun 2010, sedangkan total PAD tertinggi sebesar Rp66.233.600 dimiliki oleh Provinsi DKI Jakarta pada Tahun 2019.

4. Total pendapatan sebelum akrual basis menunjukkan mean sebesar Rp5.336.519 dengan standar deviasi Rp6.670.923 dan total pendapatan sesudah akrual basis menunjuukan mean sebesar Rp9.922.761 dengan standar deviasi Rp13.554.664. hasil menunjuukan nilai mean lebih kecil dari standar deviasi, artinya distribusi data total pendapatan tidak baik. Total pendapatan terendah sebesar Rp593.392 dimiliki oleh Provinsi Gorontalo pada Tahun 2010, sedangkan total pendapatan tertinggi sebesar Rp83.820.000 dimiliki oleh Provinsi DKI Jakarta pada Tahun 2019

\section{Uji Normalitas}

Hasil pengujian statistik One-Sample Kolmogorov-Smirnov Test menunjukkan bahwa data tidak memiliki nilai signifikansi $>0,05$ atau 5\% $(\alpha=5 \%)$. Hal ini menunjukkan bahwa data tersebut tidak berdistribusi normal. Oleh karena itu, dalam penelitian ini uji yang digunakan untuk seluruh hipotesis adalah Wilcoxon Signed Rank Test yaitu uji beda sampel berpasangan.

\section{Wilcoxon Signed Rank Test}

Hasil uji yang digunakan dengan menggunakan Wilcoxon Signed Rank Test, diperoleh hasil nilai masing2 Asymp. Sig (2-tailed) kurang dari 0,005 sehingga dapat dikatakan bahwa masing2 dari hipotesis yang telah diajukan didukung yaitu mempunyai perbedaan yang signifikan setelah penerapan akrual basis.

\section{Pembahasan}

\section{Terdapat Perbedaan Total Pendapatan-LRA dan Total Pendapatan-LO Sebelum dan Sesudah Penerapan SAP berbasis Akrual}

Hasil pengujian menunjukkan bahwa total pendapatan LRA-LRA maupun total pendapatan LRALO dalam LKPD provinsi di Indonesia memiliki perbedaan yang signifikan pada saat sebelum dan sesudah penerapan SAP berbasis akrual. Hal ini ditunjukkan dengan nilai mean pada gambar 4.1 statistik mean LRA-LRA. Nilai mean untuk total pendapatan LRA sebelum penerapan accrual basis sebesar Rp5.336.519.345.454 kemudian naik menjadi Rp9.227.285.333.333 setelah penerapan accrual basis. Total pendapatan dalam LRA saat sebelum dan setelah penerapan SAP berbasis akrual ini, tetap menggunakan 
pengakuan akuntansi yang sama, yaitu akuntansi berbasis kas.

Pada total pendapatan LRA-LO juga mengalami perbedaan yang signifikan seperti yang ditunjukkan pada gambar 4.2 statistik mean LRA-LRO. Nilai mean untuk total pendapatan-LRA sebelum penerapan accrual basis sebesar Rp5.336.519.345.454 kemudian setelah penerapan accrual basis terdapat kenaikan total pendapatan-LO dengan nilai mean sebesar Rp9.922.761.393.939. Pada uji Wilcoxon yang telah dilakukan pada penelitian ini menunjukkan adanya perbedaan yang signifikan pada total pendapatan LRA-LO, dimana menghasilkan Asymp.Sig (2-tailed) kurang dari 0,05. Hal ini dikarenakan pada total pendapatan-LRA dan total pendapatan-LO memiliki perbedaan pengakuan dalam penerapan sistem akuntansi, yaitu akuntansi berbasis kas dan berbasis akrual. Perbedaan yang signifikan ini dikarenakan pada awal tahun 2015 pemerintah Indonesia telah mewajibkan menyusun laporan keuangannya menggunakan basis akrual sesuai dengan Peraturan Pemerintah Nomor 71 Tahun 2010 tentang Standar Akuntansi Pemerintahan (SAP).

Hal ini sesuai dengan teori New Public Management yang merekomendasikan akuntansi akrual dalam penganggaran pemerintah agar mewujudkan transparansi, efektivitas, dan efisiensi dalam pelaporan keuangannya. Hasil penelitian ini juga didukung oleh penelitian yang dilakukan oleh Pramudiati (2019) dan Wibowo et al., (2018) yang mangatakan bahwa terdapat perbedaan yang signifikan pada pendapatan sebelum dan sesudah penerapan SAP berbasis akrual, serta dalam penerapan sistem akuntansi berbasis akrual ini pengakuan pendapatan pada LKPD dinyatakan lebih akurat sehingga perbandingan antara realisasi dan target semakin kecil dibandingkan sebelum penerapan SAP berbasis akrual.

\section{Terdapat perbedaan PAD Sebelum dan Sesudah Penerapan SAP berbasis Akrual}

Hasil pengujian menunjukkan bahwa Pendapatan Asli Daerah (PAD) sebelum dan sesudah penerapan SAP berbasis akrual dalam LKPD provinsi di Indonesia memiliki perbedaan yang signifikan di LRA-LRA maupun LRA-LO. Hal ini ditunjukkan dengan nilai mean pada gambar 4.1 statistik mean LRALRA. Nilai mean untuk Pendapatan Asli Daerah (PAD) dalam LRA sebelum penerapan accrual basis sebesar Rp2.668.341.733.469 kemudian naik menjadi Rp4.438.406.454.545 setelah penerapan accrual basis.

Pada komponen Pendapatan Asli Daerah (PAD) dalam LRA-LO juga mengalami perbedaan yang signifikan seperti yang ditunjukkan pada gambar 4.2 statistik mean LRA- LO. Nilai mean untuk PAD dalam LRA sebelum penerapan accrual basis sebesar Rp2.668.341.733.469 kemudian setelah penerapan accrual basis terdapat kenaikan PAD dalam LO dengan nilai mean sebesar Rp4.995.176.345.454. Pada uji Wilcoxon yang telah dilakukan pada penelitian ini menunjukkan adanya perbedaan yang signifikan pada PAD dalam LRA-LO, dimana menghasilkan Asymp. Sig (2-tailed) kurang dari 0,05.

PAD dalam setiap daerahnya memiliki kemampuan dalam menghasilkan pendapatan-pendapatan pribadinya dalam hal ini PAD memiliki peranan penting dalam hal pembangunan di daerahnya masingmasing, maka dari itu Pendapatan Asli Daerah (PAD) harus selalu ditingkatkan setiap tahunnya agar pemerintah daerah dapat membiayai sebagian dari belanja daerahnya sehingga tingkat kemandirian otonomi daerah dapat terlaksana dengan baik.

Hal ini termasuk dalam teori yang digunakan dalam penelitian ini yaitu Teori New Public Management yang menjelaskan bahwa penerapan standar akuntansi berbasis akrual di pemerintah pusat dan daerah merupakan salah satu penerapan yang baik dalam mewujudkan tata kelola pemerintahan yang baik. Hasil penelitian ini juga didukung oleh penelitian yang dilakukan oleh Subadriyah (2017) yang mengatakan bahwa Pendapatan Asli Daerah (PAD) mengalami peningkatan dibandingkan sebelum penerapan SAP berbasis akrual. Hal ini membuktikan bahwa penerapan SAP berbasis akrual memberikan pengaruh yang signifikan dalam pengelolaan keuangan pemerintah.

\section{Terdapat Perbedaan Pajak Daerah Sebelum dan Sesudah Penerapan SAP Berbasis Akrual}

Hasil pengujian menunjukkan bahwa pajak daerah sebelum dah sesudah penerapan SAP berbasis 
akrual dalam LKPD provinsi di Indonesia memiliki perbedaan yang signifikan di LRA-LRA maupun LRALO. Hal ini ditunjukkan dengan nilai mean pada gambar 4.1 statistik mean LRA-LRA. Nilai mean untuk pajak daerah-LRA sebelum penerapan accrual basis sebesar Rp2.263.524.549.998 kemudian naik menjadi Rp3.786.759.890.909 setelah penerapan accrual basis.

Pada komponen pajak daerah LRA-LO juga mengalami perbedaan yang signifikan seperti yang ditunjukkan pada gambar 4.2 statistik mean LRA-LO. Nilai mean untuk pajak daerah-LRA sebelum penerapan accrual basis sebesar Rp2.263.524.549.998 kemudian setelah penerapan accrual basis terdapat kenaikan pajak daerah-LO dengan nilai mean sebesar Rp3.824.942.375.757. Pada uji Wilcoxon yang telah dilakukan pada penelitian ini menunjukkan adanya perbedaan yang signifikan pada pajak daerah LRA- LO, dimana menghasilkan Asymp.Sig (2-tailed) kurang dari 0,05.

Pajak daerah adalah salah satu peranan masyarakat dalam penyelenggaraan otonomi daerahnya masing-masing, serta merupakan sumber pendapatan yang penting untuk pembangunan suatu daerah. Hal ini sesuai dengan teori New Public Management yang merekomendasikan akuntansi akrual dalam penganggaran pemerintah agar meningkatkan kualitas pelaporan keuangan pemerintah karena menghasilkan informasi yang lebih akuntabel, andal, dan transparan dibandingkan dengan akuntansi berbasis kas. Laporan keuangan pemerintah daerah yang disusun setelah penerapan akrual basis dapat menguntungkan stakeholder dan mengandung nilai guna yang lebih baik dari pada laporan keuangan pemerintah daerah yang disusun sebelum penerapan akrual, karena melalui informasi yang terdapat dalam laporan keuangan berbasis akrual lebih komprehensif.

Hasil penelitian ini didukung oleh penelitian yang dilakukan oleh Pramudiati (2019) dan Wibowo et al., (2018) yang mangatakan bahwa terdapat perbedaan yang signifikan pada pendapatan sebelum dan sesudah penerapan SAP berbasis akrual. Hal ini membuktikan bahwa penerapan SAP berbasis akrual memberikan pengaruh yang signifikan dalam pengelolaan keuangan pemerintah.

\section{Terdapat Perbedaan Retribusi Daerah Sebelum dan Sesudah SAP Berbasis Akrual}

Hasil pengujian menunjukkan bahwa retribusi daerah sebelum dan sesudah penerapan SAP berbasis akrual dalam LKPD provinsi di Indonesia memiliki perbedaan yang signifikan di LRA-LRA maupun LRA-LO. Hal ini ditunjukkan dengan nilai mean pada gambar 4.1 statistik mean LRA-LRA. Nilai mean untuk retribusi daerah-LRA sebelum penerapan accrual basis sebesar Rp55.923.702.825 kemudian turun menjadi Rp51.897.263.815 setelah penerapan accrual basis. Penurunan ini bisa terjadi dikarenakan dalam jenis retribusi daerah yang dipungut oleh masing-masing pemerintah daerah provinsi mengalami pasang surut yang sesuai dengan peraturan perundang- undangan yang berlaku pada saat tersebut. Hal lain yang juga dapat mempengaruhi penurunan retribusi daerah adalah faktor komunikasi, kondisi perekonomian, serta sumber daya manusia yang ada di daerahnya masing-masing.

Pada komponen retribusi daerah LRA-LO juga mengalami perbedaan yang signifikan seperti yang ditunjukkan pada gambar 4.2 statistik mean LRA-LO. Nilai mean untuk retribusi daerah-LRA sebelum penerapan accrual basis sebesar Rp55.923.702.825 kemudian setelah penerapan accrual basis terdapat penurunan pajak daerah-LO menjadi Rp52.396.264.171. Pada uji Wilcoxon yang telah dilakukan pada penelitian ini menunjukkan adanya perbedaan yang signifikan pada retribusi daerah LRA-LO, dimana menghasilkan Asymp.Sig (2-tailed) kurang dari 0,05. Hal ini dikarenakan pada retribusi daerah-LRA dan retribusi daerah-LO memiliki perbedaan pengakuan dalam penerapan sistem akuntansi, yaitu akuntansi berbasis kas dan berbasis akrual. Penurunan ini bisa terjadi dikarenakan dalam jenis retribusi daerah yang dipungut oleh masing-masing pemerintah daerah provinsi mengalami pasang surut yang sesuai dengan peraturan perundang-undangan yang berlaku pada saat tersebut. Hal lain yang juga dapat mempengaruhi penurunan retribusi daerah adalah faktor komunikasi, kondisi perekonomian, serta sumber daya manusia yang ada di daerahnya masing-masing.

Retribusi daerah merupakan salah satu peranan masyarakat dalam penyelenggaraan otonomi daerahnya masing-masing, serta merupakan sumber pendapatan yang penting untuk pembangunan suatu 
daerah. Laporan keuangan pemerintah daerah yang disusun setelah penerapan accrual basis dapat menguntungkan stakeholder dan mengandung nilai guna yang lebih baik dari pada laporan keuangan pemerintah daerah yang disusun sebelum penerapan akrual basis, karena melalui informasi yang terdapat dalam laporan keuangan berbasis akrual lebih komprehensif. Hal ini ditunjukan dengan adanya pemungutan retribusi yang disusun menggunakan basis akrual dimana penerimaan kas dari retribusi dicatat nilai nominal kas yaitu sebesar nilai rupiah yang diterima atau disahkan, sehingga merekam semua transaksi dan kegiatan ekonomi berdasarkan terjadinya transaksi.

Hal ini sesuai dengan teori New Public Management yang merekomendasikan akuntansi akrual dalam penganggaran pemerintah agar mewujudkan efektivitas dan efisiensi dalam pelaporan keuangannya. Hasil penelitian ini juga didukung oleh penelitian yang dilakukan oleh Pramudiati (2019) dan Wibowo et al., (2018) yang mangatakan bahwa terdapat perbedaan yang signifikan pada pendapatan sebelum dan sesudah penerapan SAP berbasis akrual.

\section{E. SIMPULAN DAN SARAN}

\section{Simpulan}

Berdasarkan hasil penelitian dan pembahasan yang telah dilakukan mengenai "Perbedaan Pendapatan Sebelum Dan Sesudah Penerapan SAP Berbasis Akrual Pada LKPD Provinsi di Indonesia", maka dapat disimpulkan sebagai berikut:

1. Terdapat perbedaan kenaikan yang signifikan pada total pendapatan LRA-LRA maupun total pendapatan LRA-LO dalam LKPD Provinsi Di Indonesia pada saat sebelum dan sesudah penerapan SAP berbasis akrual.

2. Terdapat perbedaan kenaikan yang signifikan pada Pendapatan Asli Daerah (PAD) LRA-LRA maupun Pendapatan Asli Daerah (PAD) LRA-LO dalam LKPD Provinsi Di Indonesia pada saat sebelum dan sesudah penerapan SAP berbasis akrual.

3. Terdapat perbedaan kenaikan yang signifikan pada pajak daerah LRA-LRA dan pajak daerah LRALO dalam LKPD Provinsi Di Indonesia sebelum dan sesudah penerapan SAP berbasis akrual.

4. Terdapat perbedaan penurunan yang signifikan pada retribusi daerah LRA-LRA dan retribusi daerah LRA-LO dalam LKPD Provinsi Di Indonesia sebelum dan sesudah penerapan SAP berbasis akrual.

\section{Keterbatasan}

Keterbatasan yang terdapat dalam penelitian ini adalah sebagai berikut :

1. Sampel dalam penelitian ini hanya menggunakan 33 Provinsi di Indonesia. Peneliti tidak memisahkan pengujian terhadap masing-masing daerah sehingga hasil penelitian ini menjadi lebih general dan tidak spesifik untuk mengetahui dampak penerapan sistem akrual pada sektor pemerintah.

2. Penelitian ini hanya menggunakan sebagian komponen Laporan Realisasi Anggaran (LRA) dan Laporan Operasional (LO) yaitu total pendapatan, Pendapatan Asli Daerah (PAD), pajak daerah, dan retribusi daerah.

\section{Saran}

Berdasarkan hasil penelitian ini, beberapa saran yang diberikan peneliti kepada peneliti selanjutnya, yaitu:

1. Peneliti selanjutnya diharapkan dapat menambah sampel penelitian terhadap masing- masing wilayah di Indonesia, seperti kabupaten/kota sehingga hasil yang diperoleh akan lebih spesifik di setiap daerahnya.

2. Peneliti selanjutnya diharapkan dapat menambah komponen laporan keuangan lainnya, sehingga mampu memaksimalkan hasil penelitian agar lebih baik lagi. 


\section{REFERENSI}

Aidoo-Buameh, J. (2014). Political Willingness to Implement Public Sector Financial Management Reforms in Ghana - Accrual Basis of Accounting. Accounting and Finance Research, 3(1), 96-105. https://doi.org/10.5430/afr.v3n1p96

DJPK Kemenkeu. (2020). Evaluasi Keuangan Daerah. http://www.djpk.kemenkeu.go.id/?paged=2\&epkb_post_type_1_category=evaluasi -keuangan-daerah

Efendi, R., Dewi, F. G., \& Gamayuni, R. R. (2018). Usefulness analysis of accrual based accounting information on local government financial statement: A qualitative study. International Journal of Scientific and Technology Research, 7(11), 10-21.

Erlina, Rambe, O. S., \& Rasdianto. (2015). Akuntansi Keuangan Daerah Berbasis Akrual. Salemba Empat.

Hyndman, N., \& Connolly, C. (2010). Accruals accounting in the public sector: A road not always taken. Journal, 22(2011), 36-45

Grace N, D. O. (2014). New Public Management and Accrual Accounting Basis for Transparency and Accountability in the Nigerian Public Sector. IOSR Journal of Business and Management, 16(7), 104-113. https://doi.org/10.9790/487x-1673104113

Hijriah. (2020). Tinjauan Perlakuan dan Penyajian Akuntansi Pendapatan Pada Pemerintah Kota Palopo. 06(01), $39-51$.

Khan, F. (2016). Comparative Analysis Between Accrual basis and Cash Basis Accounting in the Aspect of Financial Reporting [A Study on Some Selective Local Firms in Bangladesh]. SSRN Electronic Journal, September 2015. http://library1.nida.ac.th/termpaper6/sd/2554/19755.pdf

Langelo, F ., Saerang, D. P. E., \& Alexander, S. W. (2015). Analisis Penerapan Standar Akuntansi Pemerintah Berbasis Akrual Dalam Penyajian Laporan Keuangan pada Pemerintah Kota Bitung. Jurnal EMBA, 3(1), 18.

Mahmudi. (2018). Akuntansi Sektor Publik (revisi). UII Press.

Mahmudi. (2019). Analisis Laporan Keuangan Pemerintah Daerah (4th ed.). UPP STIM YKPN.

Mu'am, A. (2015). Basis Akrual dalam Akuntansi Pemerintah di Indonesia. Jurnal Lingkar Widyaiswara, 2(1), 38 46. http://juliwi.com/published/E0201/Paper0201_38-46.pdf

Peraturan Meneteri Dalam Negeri Republik Indonesia Nomor 64 Tahun 2013 Tentang Penerapan Standar Akuntansi Pemerintahan Berbasis Akrual Pada Pemerintah Daerah. 2013. Jakarta: Sekretariat Negara Republik Indonesia

Peraturan Pemerintah Nomor 24 Tahun 2005 Tentang Standar Akuntansi Pemerintahan. 2005. Jakarta: Sekretariat Negara Republik Indonesia

Peraturan Pemerintah Nomor 71 Tahun 2010 Tentang Standar Akuntansi Pemerintahan. 2010. Jakarta: Sekretariat Negara Republik Indonesia

Pramudiati, N. (2019). Kinerja Pemda Sebelum dan Setelah Penerapan SAP Berbasis Akrual. Jurnal Bisnis Dan Ekonomi, 10(1), 11-16.

Pratiwi, Y., \& Pamungkas, B. (2014). Analisis Pengakuan Pendapatan, Belanja, Dan Pembiayaan Daerah Pada Pemerintah Daerah Kota Bogor. Jurnal Ilmiah Akuntansi Kesatuan, 2(02). http://download.portalgaruda.org/article.php?article=350277\&val=5617\&title=Ana lisis Pengakuan Pendapatan, Belanja, Dan Pembiayaan Daerah Pada Pemerintah Daerah Kota Bogor

Risnaningsih. (2016). Implementasi dan Kendala Sistem Akuntansi Pemerintah Daerah Berbasis Akrual. Universitas Tribhuwana TunggadewiMalang, XI(2).

Sayidah, N., Mulyaningtyas, A., \& Winedar, M. (2015). Implementasi Konsep New Public Management Di Dinas Koperasi Dan Umkm Kota Surabaya. Jurnal Akuntansi Dan Auditing, 12(1), 39-52. https://doi.org/10.14710/jaa.v12i1.13857

Siregar, B. (2017). Akuntansi Sektor Publik. UPP STIM YKPN.

Subadriyah, S. (2017). Flypaper Effect: Sebelum Dan Sesudah Penerapan Standar Akuntansi Pemerintah Akrual. Jurnal Akuntansi Multiparadigma, 8(3), 559-570. https://doi.org/10.18202/jamal.2017.12.7073

Syarienda, Y., Basri, H., \& Fahlevi, H. (2019). Problematika Penerapan Akuntansi Berbasis Akrual Pada Pemerintah Daerah Aceh Tengah. Jurnal Perspektif Ekonomi Darussalam, 4(1), 56-68. https://doi.org/10.24815/jped.v4i1.10 